\title{
PENGEMBANGAN MEDIA PEMBELAJARAN BERBANTUKAN KOMPUTER (COMPUTER ASSISTED INSTRUCTION/CIA) UNTUK PEMBELAJARAN KIMIA SMA
}

\author{
Betty Holiwarni \\ Fakultas Keguruan dan Ilmu Pendidikan Universitas Riau
}

\begin{abstract}
The objective of this research is to develop instructional media assisted by computer which is valid, practical, and effective to instructional high school chemistry at Atomic Structure and Chemical Bonding subject. The method of this research is development research. The research is held for two years and consist of 4 stages, define, design, develop, and disseminate. The research in the first year is as far as the development stage. Research data were collected through assessment form filled by the validator. The result showed that instructional media assisted by computer which is developed for high school chemistry lesson at Atomic Structure and Chemical Bonding subject meeting the valid criteria in terms of content and construction.
\end{abstract}

Keywords: Instructional, media, assisted, computer

\section{PENDAHULUAN}

Fakta di lapangan menunjukkan bahwa berbagai indikator mutu pendidikan masih belum memperlihatkan peningkatan yang berarti, meskipun berbagai program perbaikan telah dilaksanakan seperti, penyempurnaan kurikulum, pengadaan buku ajar, peningkatan mutu guru dan tenaga pendidikan lainnya, peningkatan manajemen pendidikan, serta pengadaan fasilitas belajar. Berdasarkan data dari badan standar nasional pendidikan (BSNP) dari tahun ajaran 2007 sampai 2012 untuk sekolah menengah atas, masih banyak kompetensi-kompetensi yang belum mencapai nilai standar kelulusan pada ujian nasional.

Mata pelajaran yang diuji secara nasional untuk sekolah menengah atas jurusan IPA adalah Bahasa Indonesia, Bahasa Inggris, Matematika, Biologi, Fisika dan Kimia. Persentase kompetensi yang belum mencapai standar kelulusan pada ujian nasional untuk mata pelajaran kimia SMA di Propinsi Riau berturut-turut dari tahun 2008 sampai 2010 berkisar antara 5-46\% ; 6,3-37,5\%; 2,5-32,7\% (Betty, 2012). Kompetensi-kompetensi yang belum dikuasai oleh peserta didik diantaranya konsep atom, konsep molekul dan ikatan kimia yang terjadi dalam senyawa organik maupun anorganik.

Ilmu kimia adalah ilmu yang mencakup sejumlah aspek mengenai bahanbahan kimia. Bahan kimia termasuk semua bahan-bahan yang sehari-hari kita pegang, lihat dan cium baunya. Bahan Kimia yang dipelajari ada yang bersifat makroskopik seperti logam, larutan, garam dan dapat dipelajari secara langsung melalui penelitian dilaboratorium tetapi untuk sifat-sifat mikroskopik pada 
tingkat atom, molekul, ion dan ikatan yang membahas elektron harus dipelajari dengan metode tidak langsung misalnya dengan menggunakan media pembelajaran dan saat ini dapat menggunakan komputer atau peralatan elektronik (Chang, 2005).

Menurut Hidayatullah dkk (2007), media pembelajarn sebagai salah satu sumber belajar ikut membantu guru memperkaya wawasan anak didik. Media pembelajaran dapat membantu guru dalam menyajikan pelajaran sehingga informasi yang disajikan lebih jelas dan lebih bervariasi.

Secara umum, media pembelajaran dapat memperjelas penyajian pesan agar tidak terlalu bersifat verbalistis, dapat mengatasi keterbatasan ruang, waktu, dan daya indra, dan dapat mengatasi sikap pasif anak didik karena dapat menimbulkan kegairahan belajar, memungkinkan interaksi yang lebih langsung antara anak didik dengan lingkungan dan kenyataan, memungkinkan anak didik belajar sendiri-sendiri menurut kemampuan dan minatnya (Arif dkk, 2010).

Penggunaan komputer sebagai media pembelajaran dikenal dengan nama pembelajaran dengan bantuan komputer (Computer-Assisted Instruction/CIA). Pada dasarnya media pembelajaran berbantukan komputer dibagi menjadi dua bagian yaitu media presentasi pembelajaran dan media pembelajaran mandiri (Arsyad, 2008).

Salah satu program komputer yang dapat digunakan sebagai media pembelajaran adalah Macromedia Flash. Macromedia Flash adalah sebuah program yang dapat digunakan untuk membuat berbagai macam animasi, presentasi, game bahkan perangkat ajar (Gora dkk, 2005). Menurut Arsyad (2008) media Macromedia Flash memiliki banyak keuntungan dalam proses pembelajaran yaitu memperbaiki sistem pengajaran, lebih nyaman, kemudahan pengajaran, serta mempersingkat waktu.

Program Macromedia Flash memiliki kelebihan jika dibandingkan dengan program-program komputer lain seperti Microsoft Word atau Microsoft Power Point, yaitu kemampuan untuk menyatupadukan bahan-bahan yang telah dibuat menggunakan program-program komputer lain sehingga menghasilkan media pembelajaran utuh. Penggunaan Macromedia Flash sebagai media pembelajaran didasarkan pada kemampuannya dalam menggabungkan konsep pembelajaran dengan teknologi audiovisual yang mampu menghasilkan hal-hal baru yang dapat dimanfaatkan dalam pendidikan dan ini dikenal dengan pembelajaran berbasis multimedia. Pembelajaran berbasis multimedia tentu dapat menyajikan materi pelajaran yang lebih menarik, tidak monoton, dan memudahkan penyampaian (Chotimah, 2008).

Pada tahun 2011 beberapa orang dosen FKIP Universitas Riau melakukan penelitian pemetaan mutu pendidikan (PPMP) di propinsi Riau. Hasil penelian ini menemukan bahwa faktor penyebab peserta didik belum menguasai 
kompetensi untuk mata pelajaran kimia antara lain adalah guru belum menggunakan media dalam proses pembelajaran, baik itu yang alami atau buatan apalagi media pembelajaran yang berbasis IT. Akibatnya, pembelajaran kimia yang berhubungan dengan atom, molekul, ion dan ikatan tidak menarik, membosankan dan sulit dipahami (Betty, 2011), (Jimmi, 2011). Dari hasil penelitian ini, juga ditemukan penyebab belum digunakannya media dalam pembelajaran oleh guru adalah guru belum mampu merancang dan mengembangkan media pembelajaran sendiri sedangkan di lapangan belum tersedia media pembelajaran sesuai tujuan pembelajaran yang ingin dicapai.

Mengacu pada permasalahan-permasalahan di atas, serta belum tersedianya media untuk pembelajaran kimia di SMA, terutama untuk materi yang berhubungan dengan struktur atom dan ikatan kimia yang sesuai dengan tujuan pembelajaran yang ingin dicapai, maka melalui penelitian ini dikembangkan media pembelajaran berbantukan komputer untuk pembelajaran kimia SMA. Hasil Penelitian ini diharapkan dapat membantu guru kimia mengatasi kesulitan dalam melaksanakan pembelajaran.

\section{METODE PENELITIAN}

Penelitian ini dilaksanakan dua tahun dengan menggunakan metode penelitian pengembangan yang dikemukakan oleh Tiagarajan, Semmel, dan Semmel (1974). Kegiatan penelitian terdiri dari empat tahap dan disebut Four- $D$ Model. Empat tahap tersebut adalah tahap pendefinisian (define), perancangan (design), pengembangan (develop), Pendesiminasian (Desseminate). Penelitian pada tahun pertama difokuskan untuk merancang prototipe media pembelajaran berbantukan komputer untuk pembelajaran kimia SMA pada pokok bahasan struktur atom dan ikatan kimia yang valid. Kegiatan penelitian diawali dengan analisis kebutuhan yang meliputi: menganalisis kurikulum kimia, melakukan wawancara dengan guru dan siswa, serta mereviu literatur tentang media pembelajaran. Berdasarkan hasil analisis dirancang prototipe media pembelajaran berbantukan komputer.

Prototipe media pembelajaran berbantukan komputer yang dihasilkan divalidasi oleh validator. Kegiatan validasi dilakukan dalam bentuk tertulis dan diskusi sampai tercapai suatu kondisi yang mana validator berpendapat bahwa media pembelajaran yang dikembangkan sudah valid dan layak untuk digunakan di sekolah. Setelah proses validasi dengan validator, dilakukan revisi terhadap prototipe media pembelajaran berbantukan komputer. Diagram alir pengembangan media pembelajaran dapat dilihat pada Gambar 1. 


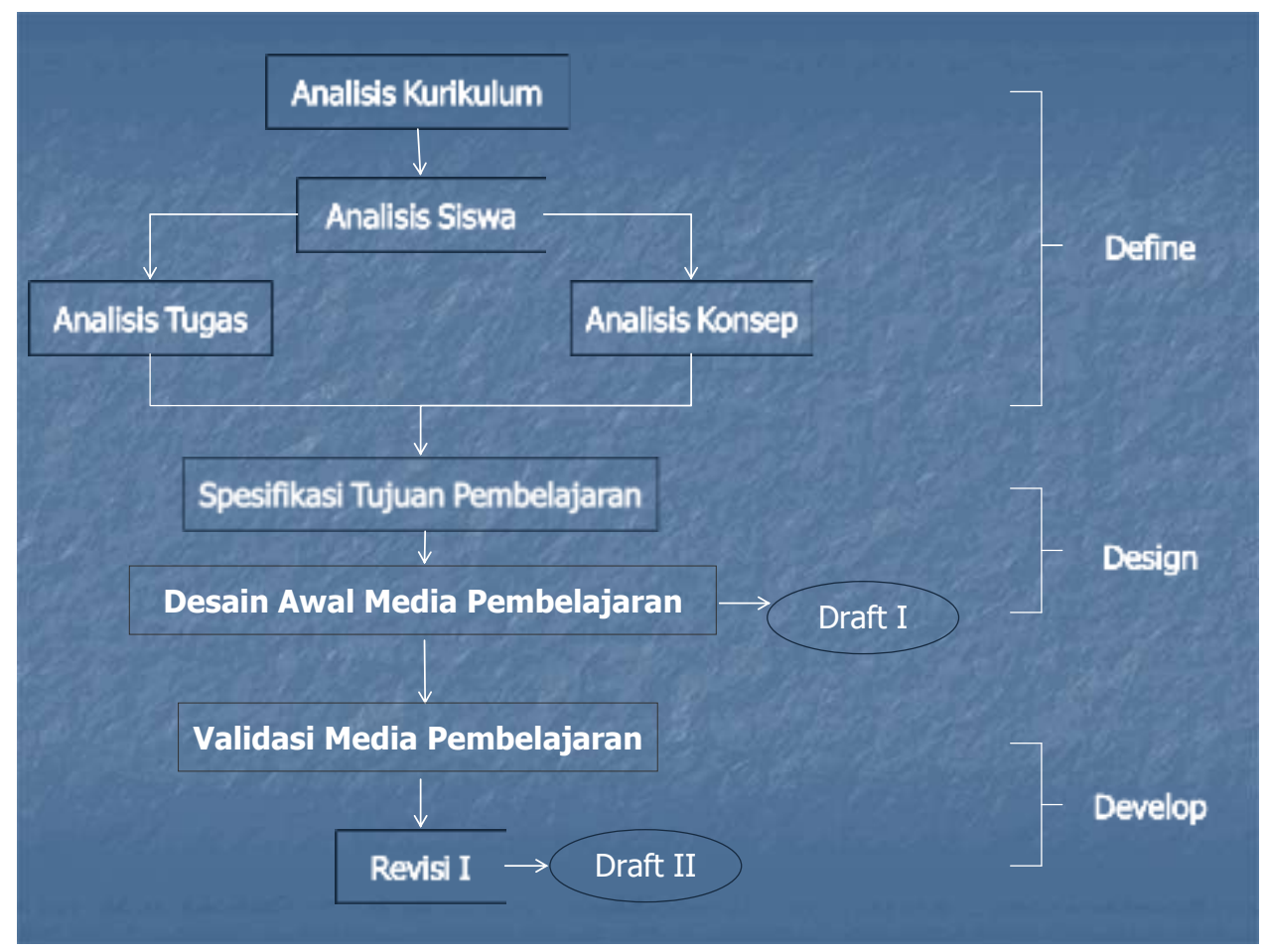

Gambar 1. Diagram Alir Pengembangan media pembelajaran berbantukan komputer

\section{a. Tahap I: Pendefinisian}

Ada lima rangkai kegiatan yang dilakukan pada tahap pendefinisian, yaitu analisis kurikulum, analisis siswa, analisis tugas, analisis konsep, serta yang terakhir merumuskan tujuan pembelajaran.

Analisis ujung-depan atau front-end analysis merupakan kajian di awal atau ujung-depan dari rangkaian langkah pengembangan media pembelajaran, khususnya kajian terhadap masalah mendasar yang dihadapi pembelajaran kimia SMA saat ini.

Analisis siswa dilakukan berdasarkan temuan penelitian terdahulu. Secara umum dapat dikatakan bahwa bekal awal siswa dalam mata pelajaran kimia baik produk, proses, maupun psikomotor rendah (Betty, 2009). Penelitian lain menemukan bahwa siswa menunjukkan minat tinggi pada saat diperkenalkan alat-alat dan dilatih cara menggunakan alat dan senang mengikuti kegiatan praktikum dan keterampilan siswa itu dapat ditingkatkan. (Nur, 2003).

Analisis tugas adalah pengidentifikasian keterampilan proses dan psikomotor yang perlu dilatihkan kepada siswa. Keterampilan proses yang harus dikuasai siswa terutama adalah keterampilan melakukan pengamatan, dan percobaan dengan benar.

Analisis konsep adalah pengidentifikasian konsep-konsep utama yang tercakup pada materi pokok (struktur atom dan ikatan kimia) yang dipilih, kemudian dibuatkan peta konsep untuk setiap konsep utama. 
Perumusan tujuan pembelajaran merupakan langkah terakhir dari tahap pendefinisian. Tujuan pembelajaran dirumuskan berdasarkan indikator dengan kata kerja operasional yang bisa diukur dan dibuat instrumen penilaiannya.

\section{b. Tahap II: Perancangan}

Pada tahap perancangan dilakukan merancang prototipe media pembelajaran. Tahap ini dapat dimulai setelah tujuan pembelajaran dirumuskan. Pemilihan format untuk media pembelajaran dan produksi versi awal media pembelajaran merupakan kegiatan utama tahap ini. Tahap kedua ini terdiri dari empat langkah berikut ini.

Pemilihan format untuk media pembelajaran mengacu pada syarat yang telah ditentukan oleh badan standar nasional (BSN). Dengan format ini, media pembelajaran yang dikembangkan memiliki karakteristik penting, antara lain pendekatan yang lebih konstruktivis dan memasukkan strategi-strategi untuk mengembangkan kemampuan berfikir kritis dan kreatif, serta pendekatan science, teknology, and society. Dengan format ini diharapkan siswa akan belajar kimia dengan senang, sementara guru mendapat kemudahan untuk mengajar kimia.

Kegiatan awal yang dilakukan adalah merancang media pembelajaran untuk kompetensi dasar pokok bahasan struktur atom dan ikatan kimia yang telah ditetapkan dalam silabus. Tahap ini menghasilkan draf I.

\section{c. Tahap III.: Pengembangan}

Tahap pengembangan bertujuan untuk menghasilkan draf media pembelajaran. Draf media pembelajaran yang telah dikembangkan divalidasi oleh validator, berdasarkan masukan dari validator draf media pembelajaran direvisi. Validasi dilakukan oleh dua orang validator. Dalam memvalidasi, validator sekaligus diminta untuk memberikan masukan dengan cara menuliskan masukannya langsung pada lembar penilaian draf I. Berdasarkan masukan tersebut, dilakukan revisi atas draf I dan menghasilkan draf II. Untuk tahun pertama penelitian, draf II merupakan produk hasil penelitian pengembangan media pembelajaran berbantukan komputer untuk pembelajaran Kimia SMA pada pokok bahasan struktur atom dan ikatan kimia.

\section{HASIL DAN PEMBAHASAN}

Pada bahagian ini akan dikemukakan hasil-hasil penelitian dan validitas media pembelajaran berbantukan komputer untuk pembelajaran kimia SMA yang telah divalidasi oleh dua orang validator. Validator yang dipilih adalah satu orang berasal dari ahli materi dan yang satu orang lagi ahli media pembelajaran. Penelaahan ditinjau dari aspek materi (konsep dan fakta), penyajian (sistematika dan ilustrasi gambar), kepedulian terhadap pembentukan sikap. 
Media pembelajaran pada pokok bahasan struktur atom dan ikatan kimia yang dihasilkan pada penelitian ini dapat dilihat pada Tabel 1.

\section{Tabel 1. Media Pembelajaran Yang Dihasilkan}

\begin{tabular}{|c|c|c|}
\hline No & Media & Tujuan Pembelajaran \\
\hline 1 & $\begin{array}{l}\text { Struktur Atom } \\
\text { a.Model Atom Dalton sampai sampai } \\
\text { model atom mekanika kuantum. } \\
\text { b.Percobaan Thomson untuk } \\
\text { menemukan elektron. } \\
\text { c.Percobaan tetes minyak } \\
\text { d.Penemuan partikel proton } \\
\text { e.Penemuan partikel neutron }\end{array}$ & $\begin{array}{l}\text { Menganalisis perkembangan model } \\
\text { atom }\end{array}$ \\
\hline 2 & $\begin{array}{l}\text { Ikatan Kimia } \\
\text { a.Ikatan Ion } \\
\text { b.Ikatan kovalen } \\
\text { c. Ikatan Logam } \\
\text { d.Bentuk molekul }\end{array}$ & $\begin{array}{l}\text { Membandingkan proses } \\
\text { pembentukan ikatan ion, kovalen, dan } \\
\text { ikatan logam serta interaksi antar } \\
\text { partikel. }\end{array}$ \\
\hline
\end{tabular}

Media pembembelajaran yang telah dikembangkan di atas telah divalidasi oleh dua orang validator. Hasil validasi media pembelajaran berbantukan komputer yang telah divalidasi oleh validator disajikan pada Tabel 2.

\section{Tabel 2. Hasil Validasi Media Pembelajaran Oleh Validator}

\begin{tabular}{|c|c|c|c|}
\hline \multirow{2}{*}{ No } & \multirow{2}{*}{ Aspek yang Ditelaah } & \multicolumn{2}{|c|}{ Nilai rata-rata dari validator } \\
\hline & & Sebelum Validasi & Setelah validasi \\
\hline 1 & $\begin{array}{l}\text { Kesesuaian materi dengan tujuan } \\
\text { pembelajaran }\end{array}$ & 4 & 4 \\
\hline 2 & Kebenaran konsep & 3,4 & 4 \\
\hline 3 & Kebenaran fakta & 3,6 & 4 \\
\hline 4 & Kebenaran materi & 3,6 & 4 \\
\hline 5 & Tampilan gambar & 3,4 & 4 \\
\hline 6 & Jenis/ukuran huruf/tulisan & 3,6 & 4 \\
\hline 7 & Penggunaan warna & 3,1 & 4 \\
\hline 8 & Penggunaan bahasa & 3,2 & 4 \\
\hline 9 & Penggunaan animasi & 3,4 & 4 \\
\hline 10 & Kepraktisan & 3,6 & 4 \\
\hline & Proporsi rata-rata penilaian & 3,49 & 4 \\
\hline
\end{tabular}

Nilai yang ditulis pada Tabel 2 di atas untuk masing-masing kriteria adalah nilai rata-rata yang diberikan kedua orang validator untuk masing-masing kriteria, kemudian untuk mendapatkan proporsi rata-rata maka nilai dari masing-masing aspek di jumlahkan dan dibagi 10 (sebanyak jenis kriteria yang dinilai). Nilai yang diberikan oleh masing-masing validator untuk setiap aspek yang dinilai adalah 1 = tidak baik, 2 = kurang baik, 3 = baik, dan $4=$ sangat baik.

Saat validasi, masing-masing validator menilai media yang dikembangkan dengan sepuluh aspek penilaian (kesesuaian materi dengan tujuan pembelajaran, kebenaran konsep, kebenaran fakta, kebenaran materi, tampilan gambar, jenis/ukuran huruf/tulisan, penggunaan warna, penggunaan bahasa, menggunaan animasi, dan kepratisan) dan nilai rata-rata dari kedua validator 
adalah yang tertera pada penilaian sebelum validasi pada Tabel 1. Setelah penilaian pada tahap pertama selesai, dilakukan diskusi antara tim peneliti dan validator untuk perbaikan perangkat media pembelajaran yang dikembangkan. Saat diskusi, validator langsung memberikan masukan sesuai dengan sepuluh aspek penilaian sebagai perbaikan untuk setiap slide media yang dikembangkan. Setelah diskusi selesai, tim pengembang langsung melakukan revisi terhadap media pembelajaran sesuai masukan dari validator. Kegiatan ini berulang sampai mencapai suatu kesepakatan dimana masing-masing validator sudah mengatakan bahwa media pembelajan yang dikembangkan sudah valid dengan memberikan nilai untuk masing-masing aspek bernilai 4 dan nilai yang diberikan oleh kedua validator adalah yang tertera pada penilaian setelah validasi pada Tabel 2.

Pada aspek kesesuaian materi dengan tujuan pembelajaran, kedua validator sudah menyatakan sepakat, hanya saja ada perubahan urutan dari slide media pembelajaran yang harus diganti. Pada aspek kebenaran konsep, kebenaran fakta, dan kebenaran materi, validator menyarankan untuk merubah, mengganti, dan menghilangkan beberapa kata karena dapat menimbulkan pengertian yang salah atau meragukan. Untuk aspek tampilan gambar ada beberapa penggantian gambar, karena gambar yang ada kurang menampakkan peristiwa yang terjadi, sedangkan komponen tersebut sangat penting untuk menjelaskan konsep. Sedangkan untuk jenis/ukuran huruf/tulisan, penggunaan warna, dan penggunaan bahasa juga ada beberapa yang harus diperbaiki, misalnya pada penggunaan warna yang kurang kontras pada suatu sisi sehingga sulit membedakan dengan sisi yang lain sehingga salah satu harus diganti dengan yang kontras, begitu juga dengan penggunaan jenis/ukuran huruf/tulisan di beberapa slide harus diganti karena ukuran dan jenis hurufnya ada yang terlalu besar dan ada yang terlalu kecil sehingga kurang serasi dengan tampilan media. Untuk penggunaan bahasa juga ada perbaikan karena adanya bahasa yang terlalu sulit untuk dipahami siswa sehingga diganti dengan bahasa yang lebih sederhana sehingga lebih mudah dipahami.

\section{KESIMPULAN DAN SARAN}

Berdasarkan pembahasan yang telah dikemukakan di atas dapat disimpulkan bahwa media pembelajaranbahan yang dikembangkan untuk pembelajaran kimia SMA pada pokok bahasan struktur atom ikatan kimia memenuhi kriteria valid dari segi isi dan konstruksi dan disarankan untuk mengujicobanya di kelas untuk melihat praktikalitas dan efektifitas media pembelajaran yang dikembangkan. 


\section{PENGHARGAAN}

Peneliti mengucapkan terima kasih kepada Fakultas Keguruan dan Ilmu Pendidikan atas dana yang telah diberikan dalam Penelitian Unggulan Fakultas Pengembangan Inovasi Pembelajaran Sekolah sehingga penelitian ini dapat dilaksanakan dengan baik.

\section{DAFTAR PUSTAKA}

Arif Sardiman, 2010. Media Pembelajaran, Jakarta: PT Rajagrafindo Persada.

Arsyad., 2008. Media Pembelajaran. Jakarta: Raja Grafindo Persada.

Chang, R. 2003. General Chemistry: The Essential Concepts. New York McGraw-Hill Companies.

Chotimah., 2008. Macromedia Flash Sebagai Media Pembelajaran. http://www.smu-net.com/main.php, (19 Agustus 2009)

Jimmi., C. 2011. Penelitian Pemetaan Mutu Pendidikan di Kota Madia PekanbaruDumai dan Kabupaten Rkan Hilir Propinsi Riau. Hasil Penelitian yang belum di Publikasikan.

Gora, Winaswan. 2005. Belajar Sendiri Membuat CD Multimedia Interaktif untuk Bahan Ajar E-Learning. Jakarta: PT Elex Media Kmputindo.

Hidayatullah, Taufiq. 2007. Secara Mudah Membuat Objek Web dengan Macrmedia Flash Profesional 8, Surabaya: Indah Surabaya.

Betty, Holiwarni. 2009. Pelaksanaan Kurikulum Berbasis Kompetensi bagi guru-guru kimia SMA di propinsi Riau. Jurnal Pilar Sains Vol.5 No.5, Pekanbaru,Maret

Betty, Holiwarni. 2011. Penelitian Pemetaan Mutu Pendidikan di Kota Dumai dan Kabupaten Rokan Hilir Propinsi Riau. Hasil Penelitian yang belum di Publikasikan.

Thiagarajan., Semmel., Semmel., 1974, Instrucsional Development for Training Teachers of Exceptional Children. A Source Book, Blomington Center of Inovasion on Teaching the Handicapped. Minneapolis Indiana University 